\title{
KERAGAMAN JENIS RAYAP PADA LAHAN PEMUKIMAN DENGAN BERBAGAI KELAS UMUR BANGUNAN
}

\author{
Termites' Diversity on the Residence Area with Various Building Age Classes \\ Arung Ezra Hasman ${ }^{1 凶}$, Musrizal Muin ${ }^{2}$, Ira Taskirawati ${ }^{3}$ \\ 1 Mahasiswa Laboratorium Pengolahan dan Pemanfaatan Hasil Hutan, Fakultas Kehutanan, Universitas Hasanuddin, Makassar \\ 2 Staf Pengajar, Laboratorium Pengolahan dan Pemanfaatan Hasil Hutan, Fakultas Kehutanan, Universitas Hasanuddin, \\ Makassar \\ ${ }^{\nabla}$ corresponding author: ezrahasman26@gmail.com
}

\begin{abstract}
Termites are organisms being widely found in residence areas, making wood components of houses as food sources and using their appropriate environments as shelter. Termites is one of the organisms that cause damage to buildings. This study aimed to determine the termite diversity with different ages of house constructions in a residence area of Makassar. The reasearch procedure applied in this research were: (1) Determination of research location using purposive sampling methods; (2) Collection and preservation of samples using Finding Colony and Casual Collection method; (3) Termites observation by identifying the morphological characteristic; and (4) Data analysis using the Shannon-Wiener index ( $\mathrm{H}$ ') to calculate the termites diversity. The result shows that the termite diversity in the research site of Perumnas Bumi Tamalanrea Permai consisted of three species, i.e. Microcerotermes serrula, Coptotermes sp., and Schedorhinotermes sp. The level of termites' diversity on each age class of buildings can be classified as "low" where the variety of termites in the building age classes of less than 8 years, 8-16 years, and more than 16 years are $0,0.39$, and 0.43 , respectively. Results also indicate that at all locations, the most common termite species found was M. serrula.
\end{abstract}

Key words: termites, termite diversity, wood construction, $\mathrm{H}^{\prime}$ index, finding colony and casual collection method.

\section{A. PENDAHULUAN}

Rayap sangat mudah ditemui di berbagai tipe ekosistem seperti ekosistem hutan, pertanian, perkebunan dan juga ditemukan di ekosistem perkotaan dan permukiman. Rayap (ordo: isoptera) tersebar luas pada berbagai tipe ekosistem di berbagai negara. Krishna et al. (2013) menunjukkan bahwa terdapat 3.106 spesies rayap di dunia yang telah diidentifikasi dan dideskripsikan. Seluruh spesies tersebut tercakup ke dalam 9 (sembilan) familia dan 282 genera (Beccaloni \& Eggleton, 2013), yaitu Mastotermitidae, Archotermopsidae, Hodotermitidae, Stolotermitidae, Kalotermitidae, Stylotermitidae, Rhinotermitidae, Serritermitidae, dan Termitidae.

Faktor penyebaran rayap ke berbagai negara disebabkan oleh introduksi manusia dalam mentransportasi kayu yang terkena dampak serangan rayap seperti melalui kayu kapal atau komoditi kayu yang digunakan di darat seperti rel kereta api (Su \& Scheffrahn, 2007). Selain itu, kondisi lingkungan yang meliputi iklim, curah hujan, suhu, tanah dan topografi merupakan faktor yang utama dalam menentukan penyebaran rayap. Variasi dari faktor-faktor tersebut turut mempengaruhi kemampuan rayap untuk melakukan adaptasi, bertahan hidup dan mengembangkan koloninya. Salah satu bentuk adaptasi, bertahan hidup dan pengembangan koloni rayap yakni dengan menjadikan bangunan rumah di sejumlah pemukiman sebagai sumber makanan dan tempat tinggal bagi rayap dengan kondisi lingkungan yang sesuai.

Hadirnya rayap di bangunan rumah menjadi suatu persoalan penting baik bagi keberlanjutan penggunaan bangunan maupun bagi penghuni rumah itu sendiri. Serangan rayap pada konstruksi bangunan merupakan masalah yang sangat mengkhawatirkan dikarenakan intensitas serangan rayap yang tinggi menyebabkan nilai kerugian yang tinggi pula. Tingginya intensitas serangan rayap pada bangunan cenderung dipengaruhi oleh fenomena perubahan pemanfaatan lahan yang sebelumnya merupakan suatu kesatuan ekosistem yang mantap (alami) menjadi peruntukan baru yang bersifat homogen dan menambah tingkat investasi dari rayap. Meningkatnya preferensi investasi rayap menjadi akibat dari penurunan kompleksitas ekosistem habitat alami rayap (Bakti, 2004). Hilangnya sumber-sumber makanan alami berdampak pada perubahan daya adaptasi rayap sehingga turut mengubah perilaku mencari makan rayap dengan memperluas areal pencarian makanannya dan memakan apapun yang ditemui. Semakin meluasnya 
wilayah pemukiman, maka interaksi antara koloni rayap dengan bangunan perumahan juga akan semakin meningkat.

Kerusakan bangunan rumah akibat serangan rayap dapat ditentukan dengan indikator umur bangunan. Umur bangunan yang tua cenderung mengalami kerusakan yang lebih banyak. Semakin tua umur bangunan maka keawetan konstruksi kayu yang ada di dalamnya cenderung menurun dan potensi serangan rayap akan semakin meningkat (Savitri, Martini, \& Yuliawati, 2016). Namun, belum tentu bangunan rumah dengan umur yang lebih muda tidak memiliki kerusakan yang juga besar, tergantung pada pemeliharaan dan perawatan yang dilakukan pada bangunan. Dengan demikian, hubungan antara umur bangunan dalam suatu perumahan dengan keragaman jenis rayap yang menghuninya perlu dikaji lebih jauh melalui penelitian. Dalam hal ini, identifikasi keragaman jenis rayap pada berbagai kelas umur bangunan rumah menjadi sangat penting.

\section{B. METODE PENELITIAN}

\section{Penentuan Lokasi Penelitian}

Pemilihan lokasi dilakukan dengan menggunakan metode purposive sampling yaitu memilih salah satu areal pemukiman. Selain itu, lokasi penelitian juga ditentukan dari hasil observasi awal akan keberadaan rayap. Dari hasil observasi lapangan maka terpilih Perumnas Bumi Tamalanrea Permai (BTP) yang terletak di Kec. Tamalanrea, Kota Makassar sebagai lokasi penelitian. Berdasarkan hasil wawancara dengan pihak pengelola, ditemukan informasi bahwa Perumnas BTP dibangun pada tahun 1989 dengan jumlah bangunan saat ini sebanyak 9.239 unit rumah/bangunan. Lokasi penelitian secara geografis dapat dilihat pada Gambar 1.

Setelah areal pemukiman ditentukan maka selanjutnya dilakukan survey dengan mengamati bangunan rumah dan lingkungannya seperti pada pohon dan tumpukan kayu yang berada disekitar bangunan rumah. Survey dilakukan pada 16 titik lokasi yang selanjutnya diberi kode lokasi $A$ hingga $P$. Seluruh titik lokasi bangunan yang ditemukan rayap kemudian diklasifikasi berdasarkan umur bangunannya ke dalam 3 (tiga) kelompok kelas yakni kelas umur <8 tahun; 8-16 tahun dan $>16$ tahun. Pemilihan klasifikasi umur bangunan tersebut didasarkan dari hasil penelitian yang dilakukan oleh Savitri et al. (2016) yang menyatakan bahwa umur bangunan rumah juga dapat menentukan tingkat kerusakan bangunan rumah akibat serangan rayap. Dijelaskan lebih lanjut bahwa umur bangunan yang paling banyak mengalami kerusakan adalah pada kelas umur 814 tahun.

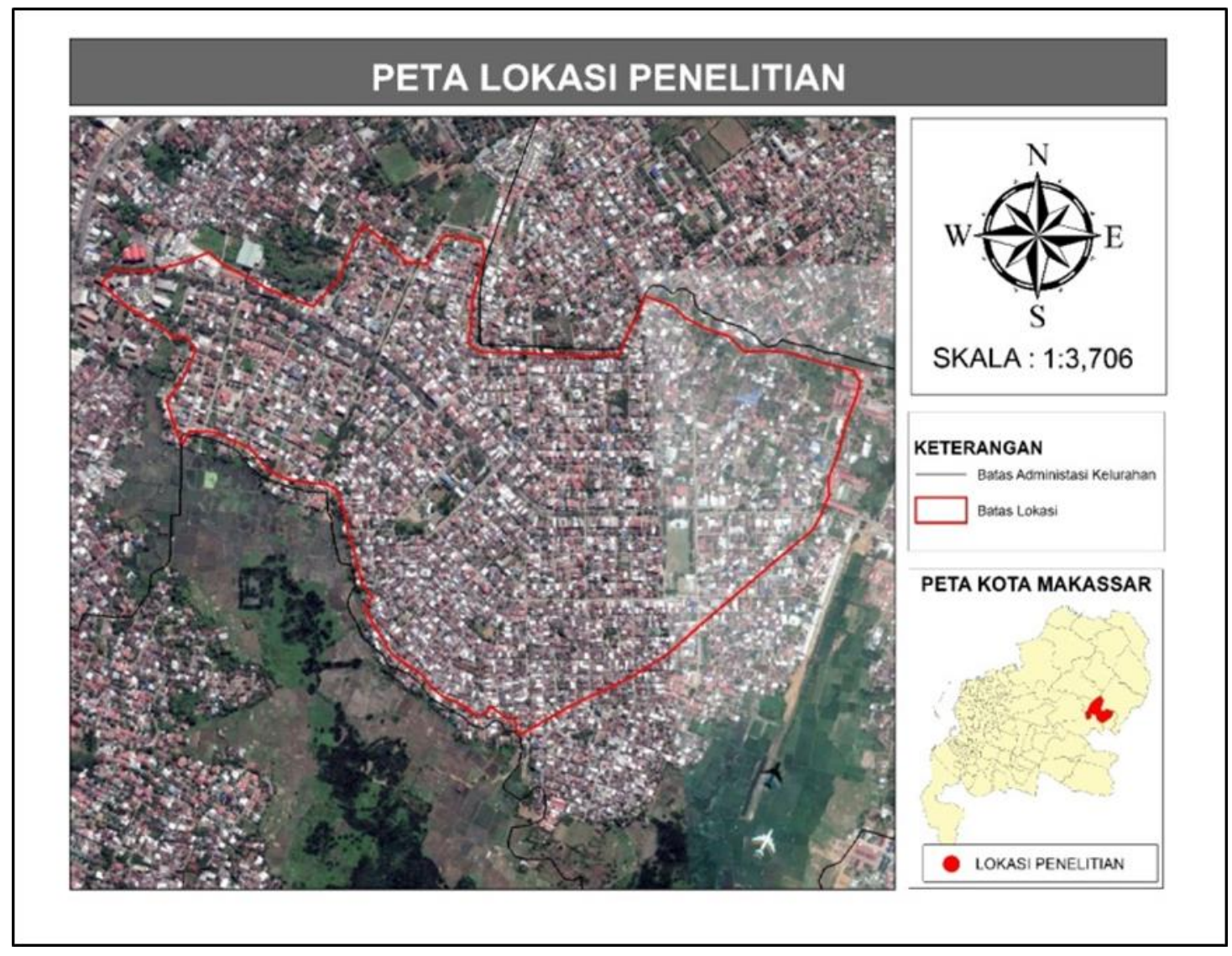

Gambar 1. Lokasi Penelitian terletak di Perumnas Bumi Tamalanrea Permai, Kec. Tamalanrea, Kota Makassar 


\section{Pengambilan, Koleksi dan Pengawetan Sampel}

Pengumpulan data rayap dilakukan dengan cara Finding Colony dan Casual Collection pada bangunan rumah dan lingkungan sekitarnya yang dianggap terdapat koloni rayap dengan melihat keberadaan serangan rayap. Masing-masing lokasi kemudian ditentukan titik koordinatnya menggunakan GPS. Untuk di lingkungan sekitar bangunan rumah dilakukan pengoleksian rayap dengan mengamati setiap mikrohabitat seperti kayu mati, ranting lapuk, gundukan tanah dan serasah. Selain itu, juga dilakukan pembukaan liang kembara pada batang pohon yang masih hidup maupun sudah mati yang diperkirakan terdapat koloni rayap. Lokasi-lokasi dari koloni rayap yang ditemukan segera didokumentasikan kemudian sarang tersebut dibuka dan rayap yang terdapat di dalamnya dikoleksi (Syaukani, 2013). Rayap yang telah ditemukan, kemudian dibersihkan dari kotoran, dikumpul dan disimpan di dalam botol sampel (vial) plus penutup yang sebelumnya telah diisi dengan etanol $70 \%$.

Pada lokasi yang ditemukannya rayap, dicatat kondisi lokasi lingkungannya antara lain: suhu dan kelembaban serta kondisi spesifik habitat rayap selanjutnya didokumentasikan. Data suhu dan kelembaban juga diperlukan karena menjadi salah satu faktor yang mempengaruhi keberadaan rayap. Pengukuran suhu dan kelembaban dilakukan dengan menggunakan Thermo-Hygrometer. Pengukuran dilakukan dengan meletakkan Thermo-Hygrometer pada titik lokasi ditemukannya rayap selama tiga sampai lima menit. Kemudian skala yang muncul pada alat tersebut didokumentasikan. Untuk mendapatkan hasil pengukuran suhu dan kelembaban yang maksimal dilakukan pengukuran sebanyak tiga kali selama tiga hari secara berturut-turut pada waktu yang sama ditemukannya rayap dan pada lokasi yang sama pula. Hasil pengukuran tersebut kemudian dirata-ratakan dan hasil perhitungan rata-rata tersebut yang diambil menjadi nilai akhir dari suhu dan kelembaban.

\section{Pengamatan Rayap}

Sampel rayap yang terkumpul kemudian diidentifikasi dengan melakukan pengamatan ciri morfologi pada pengukuran bagian kepala kasta prajurit dengan mengacu pada pendekatan yang dilakukan Takematsu et al. (2012), yaitu dengan melakukan pengukuran panjang kepala tanpa mandibel (PKTM), lebar kepala pada dasar mandibel (LKDM), lebar maksimum kepala (LMK), panjang mandibel kiri (PMK), panjang pronotum (PP), panjang maksimum pronotum (LMP), panjang posmentum (PPos), lebar posmentum (LPos), jumlah segmen antena (JSA). Dilakukan juga pengukuran indeks yaitu indeks LKDM/LMK, indeks LMK/PKTM, indeks PMK/PKTM. Pengukuran dilakukan pada rayap kasta prajurit karena jika dibandingkan dengan rayap pada kasta lainnya, pada kasta prajurit perbedaan antara rayap sangat mencolok khususnya bagian kepala yang membedakan antara genus yang satu dengan genera yang lain. Selanjutnya, rayap yang telah dikoleksi dan diukur kemudian diidentifikasi jenisnya di laboratorium dengan mengacu pada literatur kunci determinasi (Krishna et al., 2013; Sornnuwat, Vongkaluang, \& Takematsu, 2004; Tho, Kirton, \& Institut Penyelidikan Perhutanan Malaysia., 1992).

\section{Analisis Data}

Data dari hasil penelitian ini dianalisis secara deskriptif sesuai dengan hasil identifikasi pada jenis rayap yang ditemukan di lapangan. Seluruh rayap yang telah melewati proses pengamatan kemudian dihitung keragaman jenis rayap pada tiap kelas umur bangunan. Untuk menghitung keragaman jenis rayap dilakukan dengan indeks Shannon-Weiner $\left(\mathrm{H}^{\prime}\right)$

\section{HASIL DAN PEMBAHASAN}

\section{Kondisi Fisik Lokasi}

Perumnas BTP terletak di sebelah timur Kota Makassar dan berada pada ketinggian 0-20 mdpl. Perumnas BTP merupakan salah satu perumnas terbesar di Kota Makassar bahkan di Sulawesi Selatan yang terletak di Kelurahan Tamalanrea, Kecamatan Tamalanrea yang berjarak sekitar $12 \mathrm{~km}$ dari pusat Kota Makassar. Berdasarkan data yang dihimpun dari Perum Perumnas Regional VII, Perumnas Bumi Tamalanrea Permai dibangun pada tahun 1989 dan sebelumnya merupakan wilayah catchment area Kota Makassar.

Kondisi bangunan rumah di perumahan ini sangat bervariasi; kondisi pertama, terdapat bangunan yang masih mempertahankan kondisi awal berdirinya. Pada bangunan dengan kondisi pertama, kualitas bangunan rumah menurun karena seluruh elemen bangunan telah lama digunakan. Selain itu, ditemukan pula kerusakan pada beberapa bagian rumah misalnya pada atap dan dinding. Kondisi kedua yakni bangunan telah dilakukan pembaharuan berupa renovasi pada bagian interior maupun eksterior bangunan. Penggantian elemen bangunan yang mengalami kerusakan atau yang sudah lama digunakan adalah salah satu bentuk pembaharuan bangunan yang dilakukan. Kondisi ketiga yaitu terdapat bangunan rumah yang tidak berpenghuni sehingga tidak adanya perhatian terhadap bangunan dan terjadi pelapukan pada beberapa bagian rumah seperti atap dan pintu. Kondisi keempat yaitu bangunan rumah yang berpenghuni namun tidak diperhatikan oleh pemiliknya. Hal ini dibuktikan dengan ditemukannya tumpukan kayu sisa penggunaan rumah tangga yang dibiarkan hingga lapuk, tumpukan batang dan ranting pohon sisa penebangan atau pemangkasan yang dibiarkan begitu saja. Kondisi-kondisi tersebut secara mendasar dapat menjadi sumber makanan bagi rayap dan memicu berkembangnya rayap. 
Pengamatan dan pengukuran kondisi lingkungan juga dilakukan di lokasi penelitian. Kisaran suhu dan kelembaban pada masing-masing titik lokasi penelitian tidak jauh berbeda, yaitu berkisar pada $29-34^{\circ} \mathrm{C}$ dan kelembaban $55-80 \%$. Pada kondisi tersebut rayap berpotensi untuk mengembangkan koloninya. Hal tersebut sejalan dengan temuan yang dilakukan oleh Nandika, Rismayadi, \& Diba (2003) bahwa suhu optimal untuk perkembangan rayap berada pada kisaran $15-38^{\circ} \mathrm{C}$ dan kelembaban optimal berkisar pada $60-90 \%$. Suhu dan kelembaban tiap titik pengamatan dapat dilihat pada Tabel 1.

Tabel 1. Suhu dan kelembaban pada tiap titik pengamatan.

\begin{tabular}{cccc}
\hline \multirow{2}{*}{ No } & \multirow{2}{*}{ Kode Lokasi } & \multicolumn{2}{c}{ Kondisi Fisik } \\
\cline { 3 - 4 } & & Suhu $\left({ }^{\circ} \mathrm{C}\right)$ & $\mathrm{RH}(\%)$ \\
\hline 1 & $\mathrm{~A}$ & 33 & 68 \\
2 & $\mathrm{~B}$ & 33,2 & 65 \\
3 & $\mathrm{C}$ & 33,9 & 55 \\
4 & $\mathrm{D}$ & 31 & 65 \\
5 & $\mathrm{E}$ & 34,3 & 53 \\
6 & $\mathrm{~F}$ & 29 & 65 \\
7 & $\mathrm{G}$ & 34,5 & 65 \\
8 & $\mathrm{H}$ & 33,7 & 68 \\
9 & $\mathrm{I}$ & 32 & 72 \\
10 & $\mathrm{~J}$ & 32,7 & 66 \\
11 & $\mathrm{~K}$ & 33,4 & 57 \\
12 & $\mathrm{~L}$ & 35 & 67 \\
13 & $\mathrm{M}$ & 35,1 & 55 \\
14 & $\mathrm{~N}$ & 35,4 & 52 \\
15 & $\mathrm{O}$ & 33,8 & 58 \\
16 & $\mathrm{P}$ & 33 & 57 \\
\hline
\end{tabular}

Keseluruhan sampel rayap ditemukan dan dikumpulkan pada akhir musim penghujan dan awal musim kemarau. Sehingga, pada saat penelitian dilakukan, sering diperhadapkan pada kondisi cuaca yang tidak menentu, dalam hal ini kadang hujan dan kadang pula cerah.

\section{Identifikasi Jenis Rayap}

Berdasarkan hasil pengamatan morfologi dan morfometrik dari sampel rayap yang ditemukan dari 16 titik lokasi, jenis rayap yang menyerang bangunan rumah serta rayap yang ditemukan pada mikrohabitat (kayu mati, ranting lapuk, gundukan tanah dan serasah) di Perumnas Bumi Tamalanrea Permai tergolong ke dalam tiga genera yakni, Microcerotermes, Coptotermes, dan Schedorhinotermes.

\section{Genus Microcerotermes}

Genus Microcerotermes tergolong dalam famili Termitidae dengan subfamili Macrotermitinae. Pada penelitian ini ditemukan satu jenis Microcerotermes serrula. Rayap jenis ini mudah diidentifikasi dengan memperhatikan bagian kepala yang berbentuk kapsul, berwarna coklat muda, dan kedua mandibel tebal dan bergerigi. Rata-rata panjang kepala tanpa mandible 1,07$1,83 \mathrm{~mm}$, lebar maksimum kepala $0,66-1,10 \mathrm{~mm}$, lebar kepala pada dasar mandibel $0,45-0,74 \mathrm{~mm}$. Panjang postmentum $0,24-1,69 \mathrm{~mm}$, lebar maksimum postmentum 0,21-0,62 mm. Lebar minimum postmentum 0,15-0,34 $\mathrm{mm}$. Panjang dan lebar pronotum masing-masing 0,28$1,39 \mathrm{~mm}$ dan $0,20-0,92 \mathrm{~mm}$. Panjang mandibel kiri 0,40$0,92 \mathrm{~mm}$. Jumlah antena 13 segmen. Nilai indeks LKDM/LMK antara 1,46-1,80, indeks LMK/PKTM 0,551,18 dan indeks PMK/PKTM 0,33-0,67. Morfologi Microcerotermes serrula dapat dilihat pada Gambar 2.
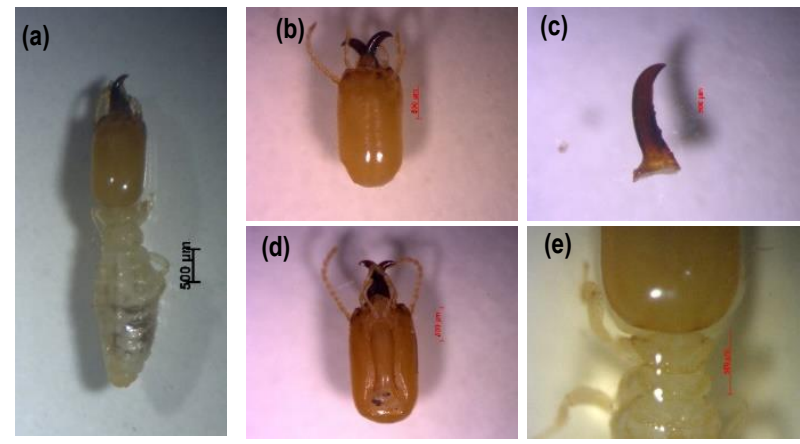

Gambar 2. Morfologi prajurit Microcerotermes serrula:(a) bentuk utuh individu prajurit, (b) bagian kepala dengan antena, (c) mandibel, (d) postmentum, dan (e) pronotum

Jenis rayap ini ditemukan pada potongan kayu, kayu gamal (Gliricidia sepium) yang lapuk, pagar kayu dan dinding bangunan rumah yang berumur 6 tahun. Jenis rayap ini ditemukan pula pada dinding rumah di lokasi lain dengan umur bangunan 12 dan 15 tahun. Jenis rayap ini paling banyak ditemui di Perumnas Bumi Tamalanrea Permai dan tidak hanya menyerang bangunan tapi juga menyerang material kayu lainnya.

\section{Genus Coptotermes}

Rayap jenis Coptotermes sp. termasuk dalam famili Rhinotermitidae dan subfamili Coptotermitinae. Ciri yang dimiliki oleh rayap Coptotermes sp. yaitu kepala berbentuk oval, bagian kepala menyempit pada bagian ujungnya yang berwarna kekuning-kuningan, dan fontanel berukuran besar pada kepala. Rata-rata panjang kepala tanpa mandibel 1,26-1,82 $\mathrm{mm}$, lebar maksimum kepala $1,07-1,50 \mathrm{~mm}$, lebar kepala pada dasar mandibel 0,62$0,89 \mathrm{~mm}$. Panjang postmentum 0,39-1,53 mm, lebar maksimum postmentum 0,40-0,83 mm, dan lebar minimum postmentum 0,19-1,06 mm. Panjang dan lebar pronotum masing-masing 0,40-0,96 mm dan 0,21-1,19 $\mathrm{mm}$. Panjang mandibel kiri 0,15-1,12. Memiliki jumlah antena 13 segmen. Nilai indeks LKDM/LMK antara 1,111,29, indeks LMK/PKTM 0,78-0,90 dan indeks PMK/PKTM 0,49-0,83. Morfologi rayap ini dapat dilihat pada Gambar 3.

Berdasarkan hasil penelitian dan identifikasi yang dilakukan, jenis rayap ini ditemukan pada batang pohon mangga yang lapuk, dan tiang bangunan penopang bangunan pos kamling yang telah berumur 10 tahun. Hal 
tersebut berkaitan dengan temuan yang dilakukan oleh Donovan, Jones, Sands, \& Eggleton (2000) yang menyebutkan bahwa preferensi makan dari rayap jenis Coptotermes sp. termasuk ke dalam Group I. Jenis rayap pada kelompok tersebut memakan kayu mati dan rumput serta memiliki karakter usus yang lebih sederhana. Jenis rayap yang tergolong ke dalam preferensi makan rayap Group I mengkonsumsi kayu dan sering dianggap sebagai hama pada bangunan yang berdampak pada kerugian finansial bagi pemilik bangunan karena mampu merusak kayu dalam waktu yang cukup singkat. Jenis rayap pada group ini cenderung bersarang pada tempat yang jauh di atas tanah.

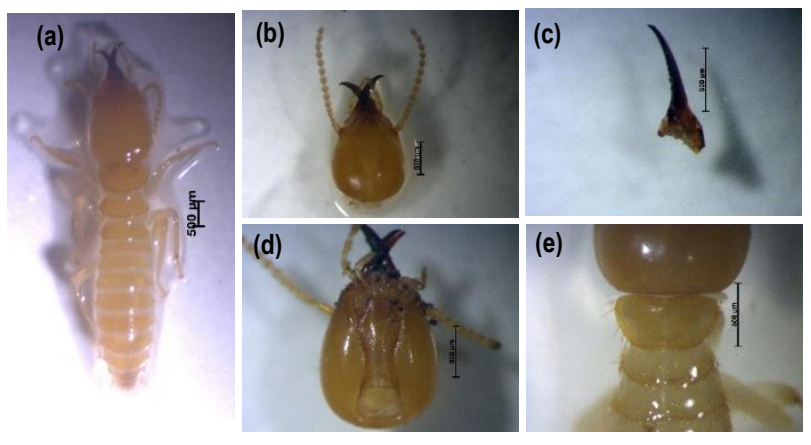

Gambar 3. Morfologi prajurit Coptotermes sp.: (a) bentuk utuh individu prajurit, (b) bagian kepala dengan antena, (c) mandibel kiri (d) postmentum, dan (e) pronotum.

\section{Genus Schedorhinotermes}

Jenis rayap Schedorhinotermes termasuk ke dalam famili Rhinotermitadae dengan subfamili Rhinotermitanae. Pada penelitian ini jenis rayap yang ditemukan yakni jenis Schedorhinotermes sp. Jenis rayap ini mampu diketahui dengan ciri-ciri kepala berwarna kuning muda, fontanel berbentuk oval, bagian kepala menyempit pada bagian ujungnya dan berwarna kekuning-kuningan serta terdapat fontal pada bagian kepala. Rayap pada kelas prajurit, bersifat dimorfik, yang berarti memiliki dua tipe prajurit yaitu tipe prajurit major yang berukuran besar dan prajurit minor yang berukuran lebih kecil. Jenis rayap ini ditemukan pada tumpukan kayu bekas penggunaan rumah tangga yang dibiarkan lapuk begitu saja dan pada kayu mangga sisa penebangan yang dibiarkan lapuk.

Karakter morfometrik jenis rayap ini terbagi dua yakni, prajurit major dan prajurit minor. Prajurit major memiliki panjang kepala tanpa mandibel 1,38-1,51 mm, lebar maksimum kepala 1,40-1,45 mm, lebar kepala pada dasar mandibel 0,87-0,90 mm. Panjang postmentum 1,20$1,25 \mathrm{~mm}$, lebar maksimum postmentum 0,40-0,41 mm dan lebar minimum postmentum 0,18-0,27 mm. Panjang dan lebar pronotum masing-masing $0,48-0,54 \mathrm{~mm}$ dan 0,73$0,88 \mathrm{~mm}$. Panjang mandibel 0,56-0,62 mm. Memiliki jumlah antena 16 segmen. Nilai indeks LKDM/LMK antara 0,96-1,07, indeks LMK/PKTM 0,93-1,04, dan indeks PMK/PKTM 0,37-0,44. Prajurit minor memiliki panjang kepala tanpa mandibel $0,93-1,10 \mathrm{~mm}$, lebar maksimum kepala 0,78-0,84 $\mathrm{mm}$ dan lebar kepala pada dasar mandibel 0,54-0,59 mm. Panjang postmentum 0,58-0,88 $\mathrm{mm}$, lebar maksimum postmentum 0,33-0,41 $\mathrm{mm}$ dan lebar minimum postmentum 0,19-0,27 mm. Panjang dan lebar pronotum masing-masing 0,27-0,42 $\mathrm{mm}$ dan 0,56$0,58 \mathrm{~mm}$. Panjang mandibel kiri 0,40-0,50 mm. Memiliki jumlah antena 14 segmen. Nilai indeks LKDM/LMK antara 1,17-1,37, indeks LMK/PKTM 0,73-0,86, dan indeks PMK/PKTM 0,37-0,49. Secara morfologi prajurit major dan minor dari jenis rayap ini dapat dilihat pada Gambar 4 dan 5.
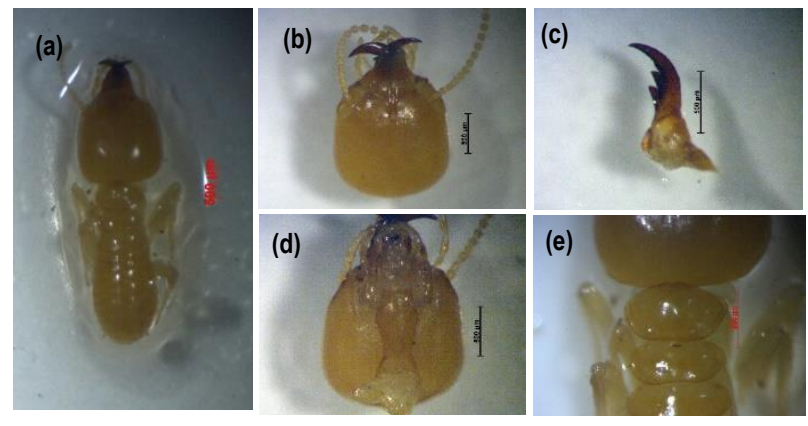

Gambar 4. Morfologi prajurit major Schedorhinotermes sp.: (a) bentuk utuh individu prajurit, (b) bagian kepala dengan antena, (c) mandibel kiri (d) postmentum, dan (e) pronotum.
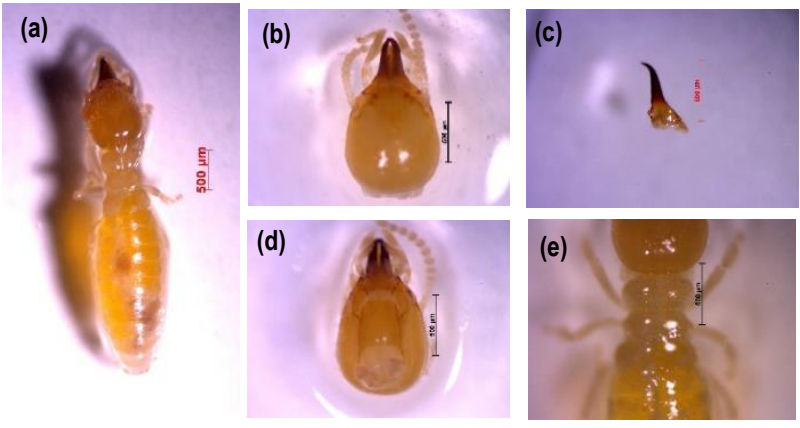

Gambar 5. Morfologi prajurit minor Schedorhinotermes sp.: (a) bentuk utuh individu prajurit, (b) bagian kepala dengan antena, (c) mandibel kiri (d) postmentum, dan (e) pronotum.

Pada penelitian ini, jenis rayap Schedorhinotermes sp. ditemukan pada kayu mangga (Mangifera indica) yang telah lapuk. Berdasarkan pengelompokan pereferensi makan dari rayap yang dikemukakan Donovan et al. (2000) rayap ini juga termasuk Group 1. Seperti pada jenis rayap Coptotermes sp. jenis rayap pada kelompok ini memakan kayu mati, serasa dan rumput serta memiliki usus yang relatif sederhana. Jenis rayap pada kelompok ini menyerang bahan yang berada di atas tanah dan selalu ditemukan terowongan yang terbuat dari tanah yang berfungsi untuk menghubungkan sarang dengan benda yang diserangnya.

\section{Sebaran Jenis Rayap}

Kondisi iklim dan tanah serta beragamnya jenis tumbuhan sangat mendukung penyebaran rayap secara luas di Indonesia. Sekurang-kurangnya 200 jenis rayap 
atau sekitar $10 \%$ dari keragaman rayap yang tersebar di seluruh dunia, dapat ditemukan di berbagai tipe ekosistem yang ada di Indonesia. Tidak hanya tersebar pada tipe ekosistem hutan, pertanian dan perkebunan, tapi ekosistem pemukiman atau perkotaan juga tak luput dari serangan rayap. Rayap diketahui sebagai serangga perusak kayu, karena sebagian jenis rayap menjadikan kayu sebagai tempat tinggal dan sumber makanannya (Nandika et al., 2003).

Dari hasil penelitian yang dilakukan, ditemukan tiga jenis rayap yang tergabung ke dalam dua famili yakni famili Rhinotermitidae dan Termitidae. Jenis rayap Microcerotermes serrula termasuk dalam famili Rhinotermitidae dan tergolong ke dalam genus Microcerotermes (Subfamili Rhinotermitinae). Jenis rayap Coptotermes sp. termasuk ke dalam famili Termitidae dan termasuk ke dalam genus Coptotermes (Subfamili Coptotermitanae). Jenis rayap Schedorhinotermes sp. termasuk ke dalam famili Rhinotermitidae dan termasuk ke dalam genus Schedorhinotermes (Subfamili Macrotermitinae). Sebaran jenis rayap yang ditemukan pada penelitian ini dapat dilihat pada Gambar 6 .

Berdasarkan pengamatan dan pengumpulan rayap yang dilakukan ditemukan adanya variasi jenis rayap berdasarkan klasifikasi umur bangunan. Jenis rayap yang ditemukan berdasarkan umur bangunan dapat dilihat pada Tabel 2.

Umur bangunan kurang dari 8 tahun yang mulai diserang oleh rayap hanya ditemukan pada lokasi $\mathrm{F}$ pada bagian dinding rumah. Microcerotermes serrula ditemukan menyerang semua kelas umur bangunan, Coptotermes sp hanya pada kelas umur bangunan 8-16 dan Schedorhinotermes sp.pada bangunan yang berumur lebih 16 tahun. Untuk lokasi $A, B, D, E, G, J$ dan $P$ tidak ditemukan rayap pada bangunan rumah.

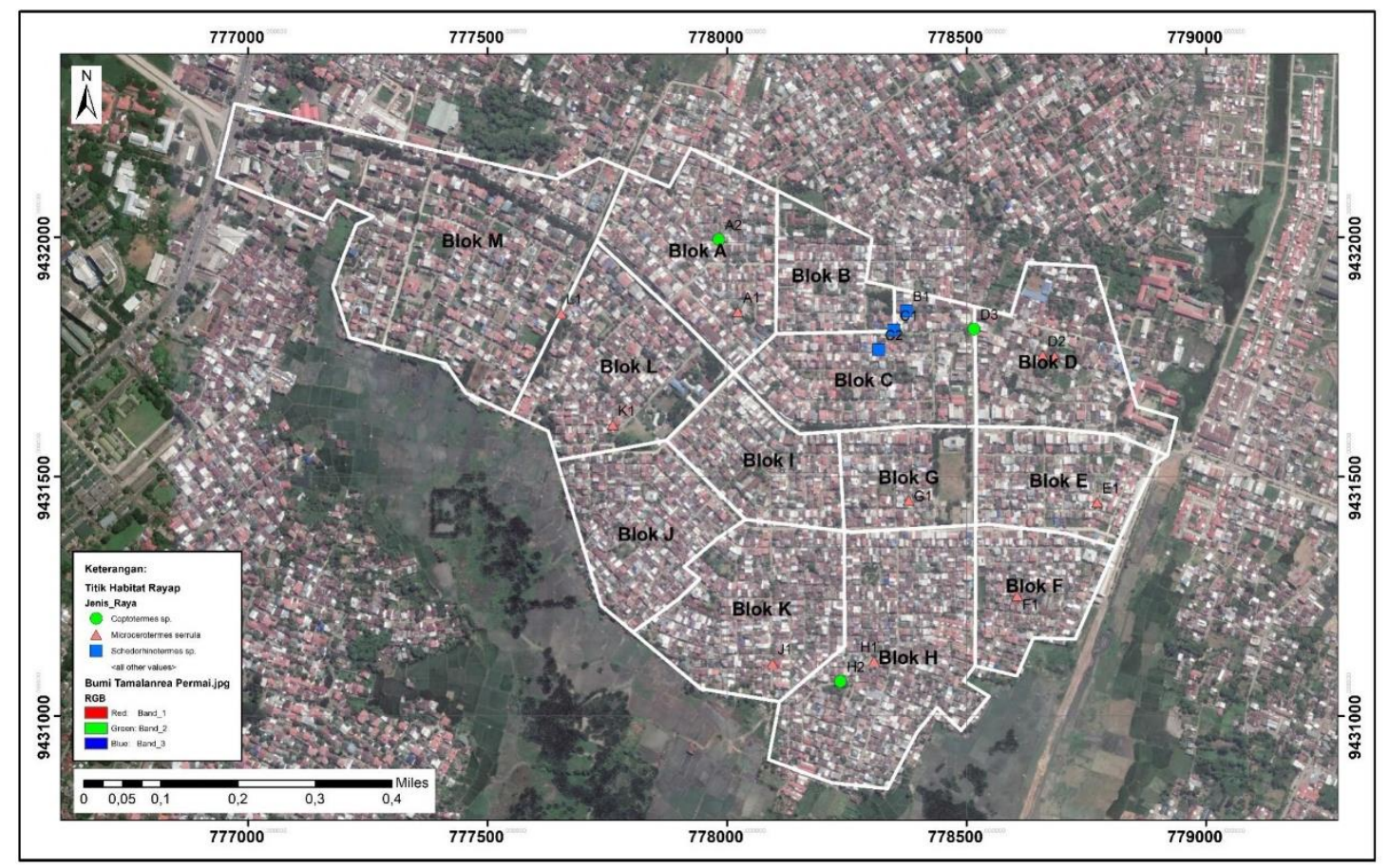

Gambar 6. Sebaran Jenis Rayap di Perumnas Bumi Tamalanrea Permai

Tabel 2. Jenis rayap yang ditemukan pada bagian bangunan rumah

\begin{tabular}{|c|c|c|c|c|c|}
\hline No & Lokasi & $\begin{array}{l}\text { Umur Bangunan } \\
\text { (Tahun) }\end{array}$ & $\begin{array}{c}\text { Klasifikasi Umur } \\
\text { Bangunan (Tahun) }\end{array}$ & Habitat Spesifik & $\begin{array}{c}\text { Jenis Rayap Berdasarkan } \\
\text { Lokasi }\end{array}$ \\
\hline 1 & $\mathrm{~F}$ & 6 & $<8$ & Dinding Rumah & Microcerotermes serrula \\
\hline 2 & $\mathrm{H}$ & 10 & & Balok Kayu & Coptotermes sp. \\
\hline 3 & M & 10 & 816 & Tiang Bangunan & Coptotermes sp. \\
\hline 4 & 0 & 12 & $8-16$ & Dinding Rumah & Microcerotermes serrula \\
\hline 5 & I & 15 & & Dinding Rumah & Microcerotermes serrula \\
\hline 6 & $\mathrm{~N}$ & 17 & & Tumpukan Kayu & Microcerotermes serrula \\
\hline 7 & C & 19 & & Papan Kayu & Schedorhinotermes sp. \\
\hline 8 & K & 19 & $>16$ & Dinding Rumah & Microcerotermes serrula \\
\hline 9 & $\mathrm{~L}$ & 20 & & Jendela Rumah & Microcerotermes serrula \\
\hline
\end{tabular}


Tabel 3. Jenis rayap yang ditemukan pada lingkungan bangunan rumah

\begin{tabular}{cccccc}
\hline No & Lokasi & $\begin{array}{c}\text { Umur Bangunan } \\
\text { (Tahun) }\end{array}$ & $\begin{array}{c}\text { Klasifikasi Umur } \\
\text { Bangunan (Tahun) }\end{array}$ & Habitat Spesifik & $\begin{array}{c}\text { Jenis Rayap Berdasarkan } \\
\text { Morfologi }\end{array}$ \\
\hline 1 & P & 8 & $<8$ & Pohon Trambesi & Microcerotermes serrula \\
\hline 2 & D & 14 & $8-16$ & Kayu Mangga & Schedorhinotermes sp. \\
3 & J & 16 & & Pagar Kayu & Microcerotermes serrula \\
\hline 4 & E & 19 & & Kayu Mangga & Schedorhinotermes sp. \\
5 & B & 20 & $>16$ & $\begin{array}{c}\text { Batang Pohon Mangga } \\
\text { Kayu Gamal }\end{array}$ & $\begin{array}{c}\text { Coptotermes sp. } \\
6\end{array}$ \\
G & 20 & & Potongan Kayu & Microcerotermes serrula \\
7 & A & 22 & & & \\
\hline
\end{tabular}

Selain ditemukan di bangunan rumah, dari hasil pengamatan dari penelitian ini ditemukan pula serangan rayap pada tumpukan kayu sisa aktivitas rumah tangga, potongan kayu yang dibiarkan terbengkalai dan di beberapa jenis pohon. Untuk lebih jelasnya dapat dilihat pada Tabel 3.

Tabel 3. menunjukkan bahwa rayap jenis Microcerotermes serrula ditemukan tersebar pada 4 lokasi yaitu $A, G, J$ dan $P$. Rayap jenis Schedorhinotermes sp. ditemukan pada 2 lokasi yaitu, E dan D. Rayap jenis Coptotermes sp. ditemukan hanya pada 1 lokasi yaitu, B. Rayap jenis Microcerotermes serrula paling banyak ditemukan. Rayap jenis ini ditemukan pada kayu-kayu lapuk seperti pada pagar kayu, kayu Gamal (Gliricidia sepium), pohon Trembesi (Samanea saman) yang sudah mati dan potongan kayu bekas penggunaan rumah tangga. Rayap jenis Coptotermes sp. ditemukan di satu titik lokasi yakni pada batang pohon Mangga (Mangifera indica) yang telah lapuk. Rayap jenis Schedorhinotermes sp. ditemukan di dua titik lokasi yang juga pada kayu Mangga (Mangifera indica) yang telah lapuk.

Serangan rayap yang menyebabkan kerusakan bangunan dipengaruhi oleh jenis rayap yang menyerang. Menurut Safaruddin (1994) jenis rayap dapat mempengaruhi intensitas kerusakan material bangunan yang terserang rayap, hal ini dilihat dari perilaku makan rayap tersebut. Pada berbagai ekosistem rayap diperhadapkan pada banyaknya pilihan makanan, dalam kondisi tersebut rayap akan memilih jenis makanan yang paling disukai. Selain itu, umur bangunan rumah juga dapat menentukan tingkat kerusakan bangunan rumah akibat serangan rayap. Berdasarkan penelitian ini, di Perumnas BTP umur bangunan yang paling banyak titik ditemukan rayap adalah pada kelas umur 8-16 tahun dan kelas umur $>16$ tahun dengan ditemukannya masingmasing tiga jenis rayap yakni Microcerotermes serrula, Coptotermes sp. dan Schedorhinotermes sp. pada empat titik lokasi dengan umur yang berbeda. Biasanya umur bangunan yang cukup tua cenderung lebih banyak mengalami kerusakan dibanding bangunan dengan umur yang lebih muda.

Pada penelitian ini, umur bangunan dengan klasifikasi lebih tua yaitu pada rentang umur $>16$ tahun diserang oleh jenis rayap yang sama dengan rentang umur
8-16 tahun yaitu Microcerotermes serrula. Hal ini dikarenakan kondisi bangunan rumah pada rentang kelas umur tersebut sudah mulai menurun sehingga materialmaterial bangunan yang telah berkurang kualitasnya (terlebih pada elemen yang berlignoselulosa) dan menjadi sumber makanan dan tempat tinggal bagi rayap. Selain itu, kurangnya perhatian masyarakat terhadap kondisi bangunan rumahnya. Masyarakat hanya melakukan renovasi atau mengganti elemen bangunan yang mengalami kerusakan dengan elemen bangunan yang baru. Pembersihan lingkungan perumahan juga kurang dilakukan, dibuktikan dengan ditemukannya tumpukan kayu bekas penggunaan rumah tangga yang bersentuhan langsung dengan tanah dan sisa penebangan atau pemangkasan pohon yang dibiarkan begitu saja dalam waktu yang lama.

\section{Keragaman Jenis Rayap}

Keragaman jenis rayap yang dijumpai pada Perumnas Bumi Tamalanrea Permai dapat dilihat dari aspek kelimpahan spesies dan indeks keragamannya.

\section{Kekayaan Spesies Rayap}

Kekayaan spesies rayap adalah jumlah total spesies rayap yang ditemukan pada transek. Kekayaan spesies rayap dapat dilihat pada Tabel 4 .

Tabel 4. Sebaran kekayaan spesies rayap pada berbagai kelas umur bangunan di Perumnas Bumi Tamalanrea Permai

\begin{tabular}{|c|c|c|c|c|}
\hline No & $\begin{array}{c}\text { Umur } \\
\text { Bangunan } \\
\text { (tahun) }\end{array}$ & Spesies Rayap & $\begin{array}{c}\text { Kelimpahan } \\
\text { (Perjumpaan) } \\
\text { Spesies }\end{array}$ & Total \\
\hline 1 & $<8$ & $\begin{array}{l}\text { Microserotermes } \\
\text { serrula. }\end{array}$ & 2 & 2 \\
\hline \multirow{3}{*}{2} & \multirow{3}{*}{$8-16$} & $\begin{array}{l}\text { Microserotermes } \\
\text { serrula. }\end{array}$ & 3 & \multirow{3}{*}{6} \\
\hline & & Coptotermes sp. & 2 & \\
\hline & & $\begin{array}{l}\text { Schedorhinotermes } \\
\text { sp. }\end{array}$ & 1 & \\
\hline \multirow{3}{*}{3} & \multirow{3}{*}{$>16$} & $\begin{array}{l}\text { Microserotermes } \\
\text { serrula. }\end{array}$ & 5 & \multirow{3}{*}{8} \\
\hline & & Coptotermes sp. & 1 & \\
\hline & & $\begin{array}{l}\text { Schedorhinotermes } \\
\text { sp. }\end{array}$ & 2 & \\
\hline
\end{tabular}


Pada Tabel 4 dapat dilihat bahwa kekayaan spesies rayap tertinggi berada pada dua kelas umur bangunan yakni pada kelas umur bangunan $>16$ tahun dengan total nilai kekayaan spesiesnya berjumlah 8 . Sementara pada kelas umur bangunan 8-16 tahun total nilai kelimpahan spesiesnya berjumlah 6 . Kelimpahan spesies yang paling rendah yaitu pada kelas umur bangunan $<8$ dengan nilai kekayaan spesiesnya berjumlah 2 .

\section{Indeks Keragaman Jenis Rayap}

Indeks keragaman spesies $\left(\mathrm{H}^{\prime}\right)$ yang diperoleh dari berbagai berbagai kelas umur bangunan di Perumnas Bumi Tamalanrea Permai dapat dilihat pada Gambar 7.

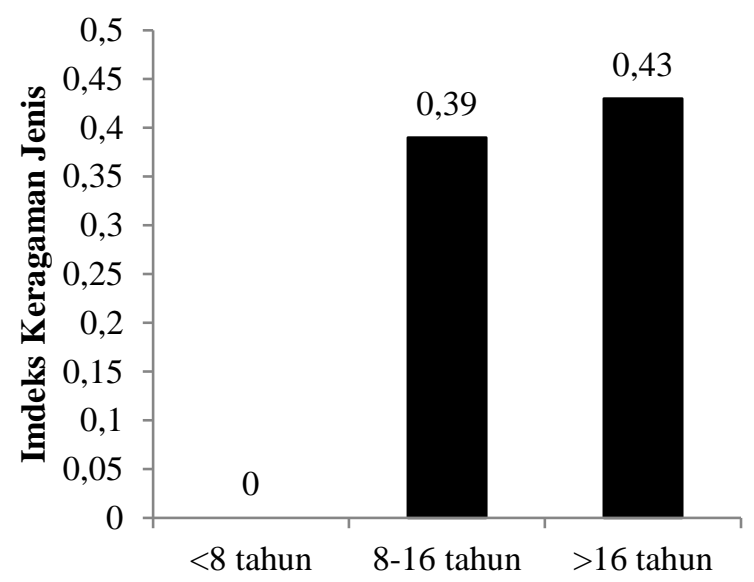

Kelas Umur Bangunan

Gambar 7. Indeks keragaman jenis Jenis Rayap di Perumnas Bumi Tamalanrea Permai

Seperti yang terlihat pada Gambar 7, keragaman yang paling tinggi berada pada kelas umur bangunan $>16$ tahun dengan nilai keragaman jenis rayapnya yakni 0,43. Sementara pada kelas umur bangunan 8-16 tahun keragaman jenis rayapnya bernilai 0,39 . Keragaman yang paling rendah yaitu pada kelas umur bangunan $<8$ tahun dengan nilai keragaman jenis rayap 0 . Nilai keragaman jenis terendah bernilai 0 karena dalam kelas umur bangunan $<8$ tahun hanya satu jenis spesies yang ditemukan. Berdasarkan kriteria indeks Shannon Wiener $\left(\mathrm{H}^{\prime}\right)$ yang menyatakan bahwa keragaman jenis rendah bila $H^{\prime}=\left\langle 1\right.$, keragaman jenis sedang bila $H^{\prime}=1-3$, dan keragaman jenis tinggi bila $H^{\prime}=>3$. Sehingga keseluruhan nilai keragaman jenis rayap pada Perumnas BTP tergolong rendah. Pada keseluruhan kelas umur bangunan, jenis rayap yang paling sering ditemui adalah jenis Microcerotermes serrula.

Pada Gambar 7. dapat diketahui pula bahwa indeks keragaman jenis rayap pada seluruh klasifikasi umur bangunan termasuk ke dalam kategori rendah. Hal tersebut diindikasikan karena lokasi penelitian merupakan lokasi dengan keadaan yang homogen. Hal ini disebabkan karena pada Perumnas BTP, faktor-faktor fisik yang mempengaruhi perkembangan rayap dalam hal ini iklim, tipe tanah, dan kondisi lingkungan cenderung sama.
Berdasarkan temuan Fatawi (2002) apabila suatu daerah atau lingkungan secara fisik semakin heterogen dan kompleks maka semakin tinggi tingkat keragaman jenisnya. Selain itu, faktor biotik dan abiotik dari lingkungan juga mempengaruhinya. Suin (2012) menyatakan rendahnya nilai indeks keanekaragaman (diversity) kemungkinan besar dipengaruhi oleh faktorfaktor lingkungan abiotik. Sebelum ditimbun dan dijadikan kawasan pemukiman, kawasan Perumnas BTP merupakan salah satu daerah tangkapan air (catchment area). Hal tersebut diasumsikan menyebabkan kelembaban di bawah permukaan tanah sepanjang kawasan cukup tinggi. Kawasan Perumnas BTP juga merupakan daerah yang sering terkena banjir setiap musim penghujan, ditambah oleh suhu yang tinggi sehingga kondisi seperti ini sangat berpotensi memicu rayap untuk terus berkembang.

\section{E. KESIMPULAN}

Keragaman jenis rayap pada Perumnas Bumi Tamalanrea Permai terdiri atas tiga jenis yaitu, Microcerotermes serrula, Coptotermes sp., dan Schedorhinotermes sp. Tingkat keragaman jenis rayap pada tiap kelas umur bangunan tergolong rendah dimana keragaman jenis rayap pada kelas umur bangunan $<8$ tahun bernilai 0 , umur bangunan 8-16 tahun bernilai 0,39 dan $>16$ tahun bernilai 0,43 . Pada keseluruhan titik lokasi, jenis rayap yang paling sering ditemukan adalah Microcerotermes serrula.

\section{DAFTAR PUSTAKA}

Bakti, D. (2004). Pengendalian rayap Coptotermes curvignathus Holmgren menggunakan nematoda Steinernema carpocapsae Weiser. dalam skala laboratorium. Jurnal Natur Indonesia, $6(2), 81-83$.

Beccaloni, G., \& Eggleton, P. (2013). Order Blattodea. Zootaxa, 3703(1), 46-48. https://doi.org/10.11646/zootaxa.3703.1.10

Donovan, S. E., Jones, D. T., Sands, W. A., \& Eggleton, P. (2000). Morphological phylogenetics of termites (Isoptera). Biological Journal of the Linnean Society, 70, 467-513.

Fatawi, Z. (2002). Studi keanekaragaman serangga tanah (Epifauna) pada berbagai ketinggian di lereng gunung ljen Kabupaten Banyuwangi. Universitas Negeri Malang.

Krishna, K., Grimaldi, D. A., Ekrishna, V., \& Engel, M. S. (2013). Treatise on the Isoptera of the world. (Bulletin of the American Museum of Natural History, no. 377). United States: American Museum of Natural History.

Nandika, D., Rismayadi, Y., \& Diba, F. (2003). Rayap : biologi dan pengendaliannya (H. J. P., Ed.). Surakarta: Muhammadiyah University Press.

Safaruddin. (1994). Kerugian Ekonomi Akibat Serangan Rayap Pada Bangunan Perumahan di Dua Wilayah DKI Jakarta (Kotamadya Jakarta Barat dan Jakarta Timur). Institut Pertanian Bogor. Bogor.

Savitri, A., Martini, \& Yuliawati, S. (2016). Keanekaragaman Jenis Rayap Tanah dan Dampak Serangan Pada Bangunan Rumah 
di Perumahan Kawasan Mijen Kota Semarang. Jurnal Kesehatan Masyarakat, 4(1), 100-105.

Sornnuwat, Y., Vongkaluang, C., \& Takematsu, Y. (2004). A systematic key to termites of Thailand. Kasetsart Journal Natural Science, 38(3), 349-368.

Su, N.-Y., \& Scheffrahn, R. (2007). Termites as Pests of Buildings. In T. Abe, D. E. Bignell, \& H. Masahiko (Eds.), Termites: Evolution, Sociality, Symbioses, Ecology (pp. 437-453). https://doi.org/10.1016/B978-0-7506-8069-1.50021-0

Suin, N. M. (2012). Ekologi Hewan Tanah. Bandung: Bumi Aksara.
Syaukani. (2013). Termites Species Richness and Distribution at Residential Area In PT Arun LNG. Jurnal Natural, 13(1), 4349.

Takematsu, Y., Yoshimura, T., Yusuf, S., Yanase, Y., Kambara, K., Tashiro, A., ... Vongkaluang, C. (2012). Termite assemlages in urban areas of south east asia: diversity and economic impacts. in: sustainable development and utilization of tropical forest resources. Kyoto. Japan.

Tho, Y. P., Kirton, L. G., \& Malaysia., I. P. P. (1992). Termites of Peninsular Malaysia. Kepong, Kuala Lumpur: Forest Research Institute Malaysia. 